\title{
Agentic practice and privileging orientations among privately educated young women
}

Claire Maxwell, Institute of Education, University of London

Peter Aggleton, UNSW, Australia

\begin{abstract}
This paper examines factors driving the agentic practices of young women who are privately educated. The analysis informing this paper comes from a three-year study, in which 91 young women aged 15-19 years were interviewed. Four private schools in one area of middle England participated in the research, and over half of the young women were re-interviewed 12-18 months later. Our starting point is the degree to which particular orientations within families are aligned to those being promoted within the various private schools in our study. The affective experiences of alignment but also of disorientation within and between the family and the school, drive significant forms of internal conversation (Archer, 2003). In this paper we examine two kinds of internal conversations found within our study - one that is assured and optimistic, and the other, which is more fractured. These different internal conversations lead to the emergence of differing projects of the self, expressed through practices that by their very nature of being committed to self directed progress can be understood as being agentic. The consequences of these different projects of the self suggest that the reproduction of class privilege cannot be taken for granted - but is always provisional and contested, even among those who are privately educated.
\end{abstract}

Keywords: agency, affect, privilege, elite education 


\section{Introduction}

Within sociology, the concept of agency has been a continuing source of debate, as writers consider how best to 'understand the interface between factors structuring and producing action' (Maxwell \& Aggleton, 2013c: 5). Agency has been engaged with in seminal books by Archer (2000, 2003), Barnes (2000) and McNay (2000); in recent theoretical journal papers by the London Feminist Salon Collective (2004), Clegg (2006), Butler (2010); as well as in empirically-informed studies within the fields of linguistics (Ahearn, 2010; Block, 2012), education (DeLissovoy, 2012; Keddie \& Williams, 2012; Vincent \& Martin, 2002; Youdell, 2006), sexuality and gender (Beavis \& Charles, 2007; Bell, 2012; Bryant \& Schofield, 2007; Currie, Kelly, \& Pomerantz, 2006; Renold \& Ringrose, 2008), and childhood (Bordonaro \& Payne, 2012; Mizen \& OfosuKusi, 2013).

In our work with privately educated young women, we too have explored the concept of agency, with a specific focus on what we have termed 'agentic practices' (Maxwell and Aggleton, 2010a, 2012a, 2013b). We prefer the use of this term to that of 'agency' because while we understand agency as, at least initially, being made possible through the indeterminacy of the subject within a particular space (see also McNay, 2000, 2003, Lapping, 2013), agency is expressed, made visible and, crucially, only has an effect through the particular social practices that it drives.

Given that our research to date has focused largely on upper and elite middle class young women [1], occupying with some degree of enthusiasm the privileged spaces of private education, we have sought to consider how agency, privilege, and also affect may be interrelated (Maxwell and Aggleton, 2013c). We have sought to explore how both the family and the school shape young women's projects of the self and their approaches to agentic practice. Ultimately, our interest lies in identifying and delineating processes that facilitate the reproduction, extension and shifting of the nature of privilege, and the orientations and aspirations the young women both develop and embody. 


\section{How does agency become possible?}

Bourdieusian-informed understandings of what makes agency possible have proved useful in our own and others' research (see for instance Allard, 2005; Bullen and Kenway, 2005; Reay et al., 2009). As McNay (2000: 72) argues, 'the logic of the field may reinforce or displace tendencies of the habitus ... it is this tension that is generative of agency'. In our own work, we understand the young women we have studied as having a habitus in the form of embodied ways of seeing, behaving, reacting, initially shaped by their families. Such pre-reflexive registers of meaning (Nielsen, 2013) are closely linked to the performance of gender, but also to the lived relations of social class, sociability, and understandings of 'success' and accomplishment, both in the present and future. Girls' actions and perspectives are shaped by their mothers', fathers' and siblings' histories and projects of the self, and in turn inform a young woman's approach to education, friendships, intimate relationships, and her future self (Maxwell and Aggleton, 2014; see also Irwin and Elley, 2013). The interaction between the habitus of the home and the institutional habitus [2] of the private school a young woman attends, however, provides important opportunities for disjucture, affirmation and other affectively-perceived outcomes.

Archer (2003: 33) argues that emotions elicited from interactions drive an 'internal conversation' through what others might see as the process of reflexivity (Crossley, 2006). The so-called first order emotions experienced during an interaction, become further articulated and develop into second order emotions through processes of discernment, deliberation and dedication (see Clegg, 2013 for a more detailed discussion). In other words, the emotional consequences of engaging with a particular discursive and affective context drive a process of reflection, which results in a growing commitment to particular sets of meanings and practices (i.e. agency). Often, agency is understood as being driven by more negative emotions - the desire for recognition (Westhaver, 2006) or the possibilities for the re-making of identities following injurious performative practices (Youdell, 2004). 
Drawing on Archer's work, however, and based on findings from our own fieldwork we would like to suggest that all emotions are capable of driving agency, not only those emotions arising from a disjuncture between the habitus and field (Reay, 2004). Thus, while we have found Bourdieu's concepts of habitus and field highly productive, we seek to engage with Archer's emphasis on emotions and reflexivity to help understand further what might be taking place for the young women in our study. For us, the internal conversation leads to a commitment to a course of action both in the present but which is also connected to future possible imaginings (Renold and Ringrose, 2008) which, if acted upon, constitutes agency.

Fundamentally, we understand the internal conversation, which a person may not always be consciously aware of, as capturing a process which occurs when emotions have consequences. We understand emotions as being socially constituted, and utilize the term 'affective' to define the structures that shape how emotions are experienced and become categorised or 'named' - as joy, despair, anger and so on. Fundamentally, emotions become generated by our movement through discursive and affective space, shaping what happens next - be this when they are barely registered, strongly suppressed or simply reacted to. Crucially, however, the internal conversation need not always consciously take place, but will always drive practice as pre-reflexive registers of meaning enfold the emotions passing through the person (see also ElderVass, 2007 [3]). Put a slightly different way, we concur with Wetherell's (2013) emphasis on the affective as being tied to 'human consciousness, discourse, representation and interpretation' (p. 228), her argument that 'affective atmospheres organise subjectivity' (p. 235), and her point that 'affected subjectivities with particular histories can also actively work to bring about, alter, maintain, resist and challenge affective atmospheres' (p. 235).

Indeed, as Archer (2012) and Nielsen (2013) have argued, different reflexive registers of meaning dominate at particular historical moments. Thus, we have found that for this particular group of young women the imperative to be reflexive seemed strongly to shape their narratives in a number of ways. This may be because particular class 
fractions have been traditionally associated with rationality and being emotionally articulate (Honey, 1977; McCulloch, 1991). Alternatively, the particular discursive constellations prevalent in the current epoch may serve to promote reflexivity and the imperative to act - with girls being understood as the ideal neoliberal subjects responsible for their own pathways to the future (Gonick et al., 2009) and all students in elite schooling contexts as being entitled to, meriting and in fact being required to succeed (Allan, 2010; Forbes \& Lingard, 2013; Gaztambide-Fernández et al., 2013; Howard, 2013; Proweller, 1998).

In this paper, we therefore seek to develop further the understandings offered by the above writers concerning the ways in which particular discursive and affective contexts shape the practices of young women in relatively privileged spaces such as the four fee-paying schools in our study. More specifically, we consider what might affect the kinds of internal conversations young women have and the ways in which particular histories and experiences within schools and families shape the kinds of first- and second-order emotions (Archer, 2003) young women experience. In other words, we would like to begin to map out the kinds of affective practices (Wetherell, 2013) that then shape agentic possibilities - or the capacity to act to meet your own needs and/or those of others - for this group of upper-middle class young women.

\section{The study}

This paper is based on findings from a three-year study of private schools in one geographical area of middle England. Funded by the UK Economic and Social Research Council (RES-062-23-2667), four schools were recruited to participate in the study, representing the diversity of fee-paying schools in that area. Of the four schools - two were boarding schools, the other two day schools. Within each of these groups one was a coeducational school, the other a single-sex school. Finally, of the four schools participating in the research, we ensured that one school was known for its high academic results nationally. The first author visited each school on an average of ten occasions over a three year period. The aim was to involve up to 25 young women in Years 10-13 (aged 14-18 years old) in the study, from each of the four schools. At least 
half (but usually two-thirds) of these participants have been followed longitudinally over a period of one year to 18 months. A total of 91 young women were interviewed for the study, with 56 being interviewed for a second time at least one year on. It is anticipated that these 56 will be re-interviewed once more in 18-24 months time, and hopefully followed up over a much longer period of time.

During the first interview, young women were asked to describe themselves, to reflect on why and how they (or their parents) had chosen to send them to the particular school they attended, and then to recount at least two experiences which had made them feel good, where they had felt in control or been proud of themselves, and two experiences which had generated less positive emotions and assessments. The latter questions were very open-ended, seeking to identify experiences where young women might identify being more or less agentic [5]. The first interviews ended by exploring what aspirations they had for their futures, including whether young women anticipated working and having a family at the same time. The follow-up discussions, one year to eighteen months on, focused on key events and experiences which had occurred in-between the two interviews - asking specifically about positive and less positive moments and whether informants felt more or less confident in various aspects of their lives and more or less sure about things now.

All interviews were audio-recorded and transcribed verbatim with permission. Data analysis has been an iterative process between the two authors, stimulated by discussion about individual young women, reflections on emotions generated during the process of interviewing and time spent in schools (Ringrose and Renold, 2013). One exercise we have engaged in has been to closely read all the transcripts and explore ways in which we might group the young women - driven by our understanding that family background and orientations, and the ease with which a young woman fitted in with the aspirations and culture of the school she was attending, would shape current and future practices (Maxwell and Aggleton, 2014). For many of the women, this process is far from seamless and not all young women fit neatly into a grouping, but the exercise has been strongly generative in helping think 
further about how privilege, the affective, and agency are mutually constituted, and how therefore the discursive and affective contexts in which young women live shape practice, and ultimately processes of class and gender reproduction.

\section{Assured optimism and reproduction of privilege}

The first group of young women we focus on here perhaps illustrates the kinds of privately educated girl subjects often imagined - the confident, accomplished, ambitious young woman whose future is more than likely to be secure-economically and socially (see also Forbes and Lingard, 2013). In order to illustrate the findings from our analysis of this particular group of young women, we have chosen to focus on four participants, one from each of the schools involved in the study. From the young women who had been assigned to this cohort during analysis, we selected those who were closest to one another in age, who were not too similar in terms of the economic, social and cultural backgrounds of their families [4], and who we had interviewed twice. In this part of the paper we explore the ways in which the close-fitting yet always slightly uneven alignments between the discursive and affective structures within families and schools shape their individual projects of the self and opportunities for internal conversation. This, in turn, affects their current and aspired-to future practices, and therefore possibilities for the reproduction of class privilege.

Each member of this group of young women tended to come from a family in which private education was a generational legacy and where other siblings had gone to equally or more prestigious schools - carefully chosen for each individual child. Brothers had often attended higher status schools, ones known internationally. Despite such an educational pedigree, not all the families were wealthy, although they could all be described as economically comfortable. Sophie's (Abbey Mill school) father was an architect who now ran a set of businesses, while her mother was a psychologist; Sadie's (St. Michael's) mother was a teacher at one of the other participating schools and her father had previously been a university lecturer but now ran his own conference-organising business. Leah's (Avonscott) mother was a parttime administrator and her father a banker. Meanwhile, Lilah's (St. George's) mother 
had been a banker and was now a trustee for a large public service organisation, while her father curated museum exhibitions whose expertise was sought across the world, as well as writing non-fiction books. Most of these young women's parents, especially their fathers, had been university-educated, the majority of them at either Oxford or Cambridge.

These young women described having parents who were actively involved in their lives, showing interest, concern, support for their various pursuits - modelling for Sadie, running and lacrosse for Leah, drama and music for Sophie. Some parents pushed their daughters in relation to academic attainment more than others. 'I was like 'I'll probably get a B in History' and they're [saying] like 'You can't get a B in History' and I'm, like ... 'Okay, I can't get a B in History then' (Lilah, St. George's, Year11). Meanwhile, Sophie (Abbey Mill, Year 12) described her parents as:

I'd say both of them are quite ambitious, but not kind of really horribly driven, you know what I mean. Like they were never pushy parents at all ... I'd say my dad's the more ambitious of the two, but he's the one who's a bit like 'Do what you want to do' [in relation to her desire to be an actor].

Leah (Avonscott, Year 12) described the kind of approach espoused by most of the parents in this group of young people, 'I feel that if I'd said that I'm going to something or if I've made a commitment I should stick to it, that's what my mum always says - I can't back out of things'.

For all four young women, the school in which they were being privately educated seemed to fit closely with their own family orientation. St. George's is the most elite school in our sample, measured in terms of the price of being educated there, a wellknown network of alumni, and by the fact that it competes against other traditional, elite schools for sports fixtures. Lilah's parents were relatively wealthy, her grandfather had been an Ambassador and her father was internationally recognised for his expertise. The family lived in a well-known upper class neighbourhood of London, side-by-side with famous actors or celebrity artists and fashion designers. The family as a whole had significant educational capital in terms of her parents' education (her father was an alumnus of St. George's), an elder sister at Oxford University and all 
four siblings had attended different, elite private (boarding) schools. Although the backgrounds of girls attending St. George's school was varied, the economic, social and educational capital evident in Lilah's family means she was not unusual in her cohort, and also illustrated the kind of demographic the school most aspired to.

Within Lilah's narrative about St. George's school, one can detect a level of ambivalence - lauding the school for 'the people [both the students and the teachers] are really good here ... I think the people are really nice' (second interview during Year 12 ), and yet feeling at times the school was 'a bit like a prison' with so many rules which were there to monitor and keep them safe (something she acknowledged was necessary). Such ambivalence may perhaps be explained by Lilah's high level of academic attainment (especially in maths and science subjects), and the significant economic, cultural and educational capital her family orientation provided for her. Despite being given the opportunity to apply for one of the most prestigious coeducational schools in London for her Sixth Form education (Years 12 and 13), and to follow in her eldest sister's footsteps, who was now at Oxford University, Lilah had decided to stay on at St. George's. This decision might be explained in part by an initial anxiety she described during her first interview (in Year 11) that she might not be as clever as her elder brother and sister and therefore sought to follow her own trajectory, in a school that was not quite so academically selective.

Abbey Mill, the other boarding school in our study, is less well known nationally, but has a long tradition of educating the daughters of the landed gentry. While Sophie did not come from a traditional upper class background, often associated with owning land in the countryside or holding an aristocratic title, her high levels of accomplishment academically and in drama and music made her a perfect fit for the current leadership team's vision of the school. Another participant from Abbey Mill described this as follows:

[The Head teacher] was saying that you should not have one string to your bow sort of. And I did feel a little bit grudgingly when I left that there was a little bit too much emphasis on 'You must be good at everything, you must at least try everything'. It's not a bad thing to have that - 'You must try everything' sort of 
ethos because it does mean you do try everything, so then you do find the things you like ... but there is a lot of emphasis on you must ... you must be academic, you must ...(Helen, Abbey Mill, one year after finishing school)

Having worked in another private school as a 'gappy' [a teaching and support assistant role that ex-private school students might do during their 'gap year', a period of time between finishing school and before starting university], Helen concluded:

Abbey Mill's never done that [selected on the basis of who is likely to attain the highest marks for exams as the school she subsequently worked in], they look for other things in girls. ... They're out to get the best [out of the] cohort that they [can] ... the pressure from the school is more that you can do this for yourself, rather than you must achieve straight $A^{*}$ s.

In Sophie's case, being 'good at everything' proved fairly easy. She was considering applying to Oxford University to study a humanities subject, but had had significant success in music theatre (having played the lead female role in a production outside school in the past year), and also sang and played in a band which regularly performed in venues near to the school. Her ease of attainment in various areas, articulation of an ambitious nature as well as expressing the significant pleasure she derived from her achievements - portrayed a young woman who was significantly accomplished, and whose family and school had managed to get the best out of her.

Sadie's parents could not afford to fund their children's education by themselves and relied on grandparent support. They had chosen a school - St. Michael's - which served a wider group of families with varying resources and differing amounts of cultural and social capital. Sadie had previously been at nearby Avonscott School [6] as her mother was a teacher there, but had moved schools due to friendship difficulties and not feeling comfortable. Her younger brother had previously moved to St. Michael's after being bullied at his last school, and subsequently both Sadie and her younger sister moved to join him there because they realised the school was 'so lovely' (interviewed during Year 13), and was in fact closer to their home. Sadie continued throughout both her interviews to position St. Michael's as the best fit for her. One narrative thread she offered concerned the disappointment she experienced at her examination results at the end of Year 11. Compared to the results her peers at her 
previous school (Avonscott) had attained, she felt she had not performed adequately. She explained that the girls at Avonscott did better because that particular school applied significant pressure on pupils to attain very high grades. She continued by saying, 'then I realised how much happier I was like in myself over here [at St.

Michael's] and how much [more] confident I became [since moving here]' (interview at Year 13). This particular statement mirrors the kind of orientation Sadie described as characterising her family - appropriately supportive but not having unrealistic, overly demanding ambitions for her - 'they're also there as kind of ... just to like guide me a little bit like. They've learnt from me that if ... they've just [got to] like set a few boundaries' (interviewed at Year 13).

Sadie was re-interviewed 18 months later, after she had left school. In discussion, the first author wondered whether it was mainly the influence of her family that had made her who she was, 'because you do come across as very grounded and you did last time I spoke to you, and confident and ... you know you're reflective about things and you kind of have a sense of yourself you know'. Sadie explained that it was both her family and her school that had made it possible for her to pursue a career as a model, equipping her to manage the significant pressures experienced within the industry, especially concerning weight loss.

I think it has got quite a bit to do with my school, 'cos obviously I did have a lot of support like. Whenever I did need time off to go work and focus on that side they were obviously like very confident that they knew I would catch up, because I was determined to do both, so they would let me have that time off and then give me any help I needed when I came back. I had a lot of support when I needed like the time out and I needed help, and obviously things were getting a bit too much. And I think my teachers also kept me very grounded as well, because they were ... I'd go and talk to my teacher, and she' $d$ be like 'Oh so how's it going?' and I'd just tell her everything that's happened. And I would like mention like the possibility of weight loss and she' $d$ be like 'I honestly don't think that like that's a good idea'. And she also kept me very grounded so I don't think ... I think it would be very easy to be caught up in it all if I didn't have such like a strong community network.

Crucially, when Sadie described the lonely life of a model, travelling for different jobs around the world, she explained it was her strong bond with her family, and her school 
friends and boyfriend, who she met at St. Michael's (all now at university), that kept her going.

Leah's family, while not without financial means, had chosen a school for her which matched her confident, ambitious nature - as Avonscott, which she attended, is known locally and nationally for its high academic results. Leah was like many of her peers at the school, where often both parents worked, but usually with one parent being the main breadwinner (usually the father). While most young women played a musical instrument or did some form of sport - at Avonscott the emphasis was usually on their academic work and creating a successful educational trajectory. Educated in a state primary school, Leah and her two brothers had been sent to different private schools for their secondary education - schools that were seen as the best fit for their academic abilities (hers were in the sciences). While her mother was not privately educated, her father had been - at Eton College - and both parents had gone to Cambridge and Oxford respectively. Thus, the academic credentials held by her parents made the fit between Leah and Avonscott natural. Leah explained her family's values as:

Like we don't have like all the Playstations or whatever. I don't get like that many presents like, which some people at this school seem to get. But then we do have enough money and we go on really good holidays and things. So I think we spend the money on more important things like school (first interview, Year 12).

Similarly, she perceived the school to be:

Like the thing that I like about Avonscott is that it is a private school but it's not like 'Hey look at us, we're so great'. Like ... I don't know, [the local boy's elite school - who have an international reputation are] a lot like that. And other schools kind of dress themselves up a bit more, and I thought our school was really down to earth ... like informal family feel (second interview during Year 13).

Thus, although she noted during her second interview that she felt the school was becoming a bit 'more snobby', which she felt was 'a shame' although understandable given market competition, Leah could be argued to portray the perfect kind of 
Avonscott girl - quietly and unassumingly ambitious academically, as well as excelling in another area - in Leah's case cross-country running.

In summary, Lilah, Sophie, Sadie and Leah came from families with material and/or other resources, where expectations of their daughters were high but aligned with their own significant capabilities, and where parents were perceived as being supportive. For all four young women, their school appeared to offer the right fit and all enjoyed largely positive relationships with teachers and peers. They articulated confident, aspiring projects of the self (both current and future trajectories), as young women who would achieve academically as well as in their extra-curricular pursuits. Their narrative voice was measured, yet suggested confidence and a sense of surety about their worth and futures - constituting an assured optimism in other words (Forbes and Lingard, 2013).

I'd like to think I'm academic, I don't know really. I'm not doing specifically academic A Levels [Year 13 examinations], but that's just because of the route I want to take. But if I wasn't going to go to drama school, I'd quite like to go to ... possibly to Oxbridge [Oxford or Cambridge Universities] to do Theology ... I was also always planning on a gap year [a year break between finishing school and starting university], so I think maybe ... spend a year sort of refining things that I haven't had the time to during Sixth Form [Years 12 and 13] because of A Levels, and then apply for the drama and uni at the end ... I think by then I'll definitely know what's best for me. (Sophie, Abbey Mill, Year 12).

Similar to Sophie, Leah was academically very able. In the extract below, Leah explains how she understands herself as 'bright', despite the highs level of academic attainment expected of all girls at Avonscott, which for some created an unrealistic picture of who was average in terms of achievement.

Claire And how do you see yourself academically?

Leah Um ... quite bright I guess. I got ... what did I get? $-9 A^{*} s$ and an A at GCSE [examinations at end of Year 11].

Claire That's fairly good really isn't it? (laughs)

Leah I think it's quite hard to see ... to know where you are in the whole country until you do GCSEs. ... People [here are] ... yeah, proper proper clever, yeah.

Claire But do you ... see yourself as clever, or do you see yourself as slightly less clever because there are other people you think are cleverer? 
Leah Um ... well once it's put into perspective with GCSEs I think that I am clever. But a lot of people wouldn't do that and don't, and think about ... compare themselves to each other and people at the school way too much.

Leah explained she become more confident about her ability to do well academically after realising that if she revised 'hard then I can definitely do it' and because her teachers had encouraged her to aim for an $A^{*}$, the highest possible grade.

Thus for this group of young women, the discursive and affective contexts within their families and schools were quite similar. Positive experiences and personal reflections were reinforced both by their families and schools - suggesting the development of a project of the self relatively uncomplicated by the few disjunctures experienced, as well as positive affective alignments imbued by an affective atmosphere promoting a sense of assured optimism (Forbes and Lingard, 2013; Wetherell, 2013). An agentic approach to forging a personal trajectory is embedded within the broader discursive and affective orientations of each of the families and schools highlighted here. These young women were engaging in the beginnings of an assured internal conversation, most clearly articulated above in the narrative segments from Sophie and Leah. What was significant, however, is that assured optimism in their own capabilities and their right to act, meant that both Sophie and Leah appeared to be forging a relatively unique future trajectory, which did not necessarily tie to the model trajectories espoused by Abbey Mill or Avonscott - both of whom seemed keen to promote that their (female) graduates work in science (as well as some other traditional career paths such as law).

When Leah, for instance was interviewed four months into Year 12 , she was still unsure what she might want to study at university. She mused about a possible future in development work,

Leah: ... Human Geography is so interesting, and it's really relevant. ... it would be like a good foundation to be about to help people like do a job that could not like well yeah make a difference

Claire: ... that's kind of what is motivating to think about what you'd like to do is those ideals ... 
Leah: I think that my parents have brought me up in a way that like ... like obviously money's important but [they are] not very like commercial, is that a word like ... like I don't have many designer clothes ...

Although international development might not form part of the traditional professions most actively promoted by Avonscott, it does still tie into the private school culture of charitable giving and a focus on those less fortunate (Maxwell and Aggleton, 2013a; Allan and Charles, 2014). However, when Leah was interviewed for the second time, half way through Year 13, she had decided to study Sports Science at university, which 'no one has ever done ... from this school before (laughs)'. She thought eventually such a choice would led her to becoming a Physical Education teacher. Similarly, Sophie, who had a strong interest in Theology (appropriate for a school that still wove a number of religious elements into the school week, such as required chapel attendance) and the potential to study such a subject at an elite university (Oxford), was leaning towards applying to drama school after completing her schooling, a significantly riskier (financial) strategy for the future.

In her first interview during her final year at school, Sadie (St. Michael's) described how she had already decided to take a year or two off after completing her secondary schooling before starting 'uni' to pursue a modelling career, albeit temporarily. During her second interview, which took place ten months after finishing school, she explained that her modelling agency was attempting to make her 'the next big thing'. Although during the first six months of working as a full-time model this had not yet happened, Sadie (with her parents' support) was committed to the experience of being a model and was actively navigating the difficult line between the expectations of the industry and time with her boyfriend and family. Despite the lure of making it big, this 18-year-old knew modelling would only be a one-to-two-year experience and was already planning which universities to apply for, in order to resume the more standard trajectory her peers were pursuing.

Meanwhile, Lilah (St. George's), during her first interview, when she was in Year 11, appeared a little less sure whether, at least compared to her older brother and sister, she was as clever as the rest of her family. However, following confirmation of her 
abilities in the form of high end-of-Year 11 GCSE results, she explained during her second interview (one year on) that she felt 'more myself than I was last year', less concerned with fitting in, and was planning to follow her siblings to a high prestige university and a career in London City as a banker.

Overall, therefore, and for this group of four young, privately educated women, all from different schools, we can see how a close fit between the discursive contexts and affective structures of family and school made possible an assured project of the self, which through positive emotional experiences allowed them to navigate a personal trajectory they appeared content with, and which would in all likelihood reproduce the particular resources and orientations espoused by both family and school. Follow up study will of course reveal whether or not this is the case.

\section{Fractured surety of the self and the limits to agenctic practice}

In our analysis, we also identified a second group of young women whose economic, cultural and educational family orientations should have proved a close fit to the particular schools they were attending, but for whom particular experiences had led to a more fractured sense of surety. This was reflected both in their present narration of the project of the self and in their future plans. Here, drawing on two examples of young women within this group (to facilitate more in-depth analysis), we examine how such disorientation appeared to affect the practices they engaged in, and subsequently the degree to which privilege was not as smoothly reproduced as in the first group of young women focused on. Our point here is both theoretical and more mundane: in that even elite class reproduction is never assured but must be constantly struggled for, sometimes against significant difficulties (see also Maxwell and Aggleton, 2014).

Disorientations can occur within the realm of the family, the context of schooling or both. Sometimes the family or the school may act as a stabilising context when difficulties have been experienced in the other setting. Or, we may observe the opposite effect, when the school or the family reinforce the effects of the initial disturbance. 
For Sasha (St. Michael's, Year 13), the affective context of her family had been unsettled - with her parents divorcing when she was very young, her mother moving around England and internationally for her job, as well as becoming seriously alcohol dependent, and the relatively recent introduction of a step-father with whom Sasha did not get on - 'we are very very different people, he's very black and white, and I'm very colour, and we don't match'. Sasha explained she had had an eating disorder and had had various psychiatric and psychological assessments, the need for which she attributed in part to her unconventional upbringing. More positively, she felt her emotional difficulties made her 'an eccentric', able to see 'beauty in like everything'. Sasha had initially attended the private school at which her mother had been a Headgirl (a school with a national reputation, which secures very high academic results), but explained,

I reached kind of 15 [years of age], and just went 'I'm sick of being told what to wear and being told what to do because it's not me'. And some of my friends were really thriving in that environment ... and I mean my GCSEs [Year 11 exams] I got were really good, came here with an academic scholarship ...

She subsequently moved to St. Michael's for the Sixth Form (Years 12 and 13) and concluded, '[at] this kind of school I'm really kind of valued for the person I actually am, and that's meant a lot'. The perceived acceptance of her eccentric, artistic self by her school and new peers, as well as her relationship with her current boyfriend had stabilised her 'scatty' nature, where her mind 'moves really fast'.

[The relationship] has been really amazing, because that's built from about a year's friendship. So it's very different to anything I had before, it's not like one of those teenage relationships, it means a lot. ... is a lot more than any other kind of therapy or my parents have said it really has kind of helped me kind of settle, having someone that's like kind of level headed, I mean he's a vaguely level headed person. He's my kind of window to reality.

Sasha's history of emotional well-being difficulties and statements such as, 'I could detach myself very easily from people' suggests a more fractured surety in the self and a somewhat disorientated sense of belonging and being valued. Several times during the course of the interview she explained that her parents had wanted her to primarily focus on academic accomplishments and on a future trajectory that would be well 
remunerated in a recognised profession (such as her mother and step-father who were doctors).

I think you know my parents would say you know 'You have the potential to be really clever' I'm like 'Yeah but it was a potential and I was being driven to like death'. And it was kind of like ... every kid can be spoon-fed something until they learn it, but actually I don't want to learn all about like Chemistry, I want to do like some crazier stuff and just blow people's minds with like music and art.

It was only when she moved to St. Michael's that she experienced a discursive and affective context that made her feel special, indulging her creative desires while still applying to top-rated universities for her chosen subject. Overall, the tone of Sasha's narrative in the interview was one of confidence, trying a little to shock or unsettle the first author, with her relative openness about her experiences. However, the listener was left with a strong sense of an underlying fragility, in which the narrative served a means for over-compensating and securing a 'care-less', individualised, but exceptional trajectory. So, despite the school providing some sort of haven, and Sasha having access to the opportunities to develop a successful, intellectually and creatively fulfilling future career through performing arts work and study at a high profile university in her chosen social science subject, the disorientations experienced within her family had left a mark. Her reflections suggest an internal conversation which is working hard to bring together and smooth over a fractured sense of belonging and self-worth. Sasha was seeking, through the process of the internal conversation, in part shared with us through the narrative created within the interview context, both to conform to the expectations of young women who are privately educated (to succeed academically and to socially and physically embody an 'acceptable' femininity - also espoused by her parents), and to stabilize an identity which combined being unique and worthy, but also successful. In contrast to the assuredness with which young women like Lilah, Sadie, Leah and Sophie (described above) visualise and commit to forging a trajectory which mirrors the pathways espoused by their families and schools in most respects, Sasha's project of the self and the practices this subsequently shaped 
appears less secure, with arguably the reproduction of privilege potentially being fragile.

Meanwhile, Anna (St. George's, interviewed twice - in Year 10 and Year 11) had experienced a series of major disorientations both within her family and within the school. These experiences had significantly shaken her surety in the self - both in the present and for the future. Anna's family appeared to be wealthy, owning three properties in England and two others abroad. Her father was a self-made entrepreneur and neither parent had been privately educated. All three children were attending elite schools, in particular her brother who was at one of the elite boy's boarding schools in England - Harrow School. Anna's best friend, Issy, had previously been interviewed as part of the study and we were expecting to encounter an overconfident, brash, unreflective young woman, given the description provided by Issy, who had experienced significant hurt as Anna's on-and-off best friend. Instead, the first author found herself sitting in a small boarding house room, with a petite, 15year-old young woman, kicking her feet in large hightop trainers while sitting on the bed, seemingly relaxed and talking openly about herself. Anna certainly gave the impression of fitting into St. George's - of having friends, enjoying her time there, perhaps not working hard enough, but feeling comfortable, 'I'm just always up for doing something' she explained.

However, disorientations within her family and the school had taken their toll. Talking about what kind of a parent she might want to be in the future, Anna confided:

Not travel so much, live in one place, l'd want a closer relationship with my kids with like um ... like I love my mum so much and I do get on with her quite a lot, but I don't really have that much of a close relationship, whereas loads of girls in boarding have like an unbelievable bond with their mum - like they tell her absolutely everything - stuff I'd tell my sister.

She described conflict with her mother over her level of application and commitment to work - 'it gets more annoying if actually you are trying in a subject and [my mum's] like, 'You can do better'; it's like, 'Well no I can't, I'm like trying as hard as I can'. Meanwhile, at school, while she gave the impression of having many friends and 
feeling comfortable, she suggested that she preferred not to be the focus of attention - I'm even nervous like to walk into like our lunch room ... I just don't like people like staring at me, it just completely freaks me out'. She also alluded to some disrespectful and harassing behaviour by some of the young men in her year towards their female peers - but was quick to establish she had not been the recipient of such attentions ('I'm personally not affected').

During her second interview, one year later, these initial fissures had opened up quite significantly. Her father had been having an affair which had been dramatically discovered by her elder sister; while at school a sexual image of Anna taken, according to her, innocently by her best female friend, had been appropriated by a male peer and sent round the school. This had culminated in the young man being expelled and because the exact context in which the picture had been taken and then distributed was not known by most of her school peers, Anna had experienced a series of abusive verbal assaults and physical threats, and was being blamed for the perpetrator's expulsion.

I didn't go to [my mum] at all [when the initial incident at school happened] because I didn't want them ... like I didn't want her to have to be with him [her dad, whose adultery had just been made public within her family]. Because she'd have to sit with him and I thought that would be really horrible for her. So then she got really upset because then I hadn't told (inaudible) anyone through it. And she was kind of upset that I didn't, and then she thought ... then it was just a bit of a mess.

These events seriously impacted on Anna's project of the self as narrated during her second interview. For instance, she was finding it impossible to end her two-year-long relationship with her boyfriend.

I've tried to do it like four times, like seriously. But there's just like literally no way out of it, because like he'll just like buy me loads of things or like send me loads of letters, there's just like physically no way out, he's always at my school. There's just kind of no way of getting out. It's kind of annoying but at the same time ... I don't know, it's kind of sweet, but I don't know it's kind of annoying. ... I don't want to like lose someone like [as a friend] ... I just can't really be bothered to fight. It's not like it's like bothering me. At the moment I've not 
seen him in like a week and a bit because l've been doing my work. So it's not any bother him being there.

Recent events seemed to have reduced her ability to act decisively for fear, perhaps, of losing the support mechanisms she currently had. The disorientations experienced also elicited uncertainty about the future - in relation to a career trajectory (should she be a journalist or a doctor, the former was being made more difficult by the internet and the latter meant 'you've got like no spare time to do anything and I really want to enjoy my life') - while also leading to a strong conviction that, despite speaking positively during her first interview of wanting a family, living in one place and having a close relationship with her children, she was now sure that 'I don't ever want to get married anymore, I don't want to ever have children'.

During the second interview, once she had begun to talk about the difficulties she had been experiencing, Anna appeared to make little attempt - either within the interview itself or the current practices narrated - to re-appropriate or re-cast her fractured project of the self. She seemed at that particular moment in time to be beginning the process of recognising the emotions these disorientations had elicited, and an internal conversation that responded almost aggressively to the hurt felt, by rejecting much of what had been expected for her by her family, school and even herself. Thus, discursive and affective disjuctures also drive agency here, but the reproduction of elite gender and class expectations appeared to be at some risk. While Anna's family's wealth seems likely to ensure she remains economically secure, and there will remain many points along her trajectory where the orientation of her family and her school exert pressure to fit more closely with the idealised privately-educated woman, the significant disorientations experienced by Anna seem likely, as they did for Sasha, to leave a trace unsettling of any straightforward reproduction of class privilege.

\section{Conclusions}

Our aim in this paper has been to think carefully about how the family and the school shape the potential for agentic practice among privately educated young women. We have suggested that both alignment and disjucture between the discursive and 
affective contexts of the family and school hold the potential to drive young women's agency. Through our analysis of the narratives described, we have sought to focus on the structural and micro processes shaping agentic practices. Thus, orientations towards the present and future espoused by families may be affirmed or challenged by young women's experiences of their schooling. The ways in which young women experience the discursive expectations of the home and school, and the alignment of emotion between these drives an internal conversation which shapes the individual young women's contemporaneous and future projects of the self. These projects themselves are made visible through the agentic practices in which young women engage and imagine.

Most young women in our study appear to be developing a project of the self bounded by broader neoliberal discourses of a committed, ambitious but appropriately gendered (Allan, 2010; Allan and Charles, 2014; Proweller, 1998; Wardman et al., 2010, 2013) privately educated girl subject. Yet, when we look closely at how these discourses are interpreted within individual families, where families' own biographies shape more specific orientations, it is possible to argue that the reproduction of privilege is far from seamless. Importantly, the pre-reflexive registers of meaning about the self, and the gendered and classed ways of seeing, moving, behaving and aspiring that young women take with them into private schooling continue to be extended, shifted and unevenly reproduced within this latter setting and beyond.

Inspired by Archer's (2003) conceptualisation of the internal conversation, we understand this process to be shaped by the degree of fit or mis-match between the home and school context for each young woman. In this paper we have shown young women engaged in assured internal conversations who forge optimistic projects of the self which continue to tie reasonably closely to expectations. We have also introduced two young women, who illustrate the experiences of another smaller group of young women we have met who described more fractured internal conversations, in which there is significantly less surety and assuredness about the future and about the kinds of classed and gendered expectations of privilege they will reproduce. In the course of 
our study we have found other young women who engage in yet further different kinds of internal conversations - such as aggressively competitive ones, or more timidly emerging processes of reflection - which too appear to be driven by different kinds of alignments and disorientations between the family and the school context. These findings will be explored in detail elsewhere. From our analysis of young women who closely fit the private school girl subject, it appears that the outcomes of private education, both for the individuals concerned and for the reproduction of class privilege, may not be quite as assured as has previously been suggested (Allan, 2009, Connell et al., 1982, Gaztambide-Fernández, 2009, Howard, 2013, Khan, 2011, Maxwell and Maxwell, 1995, Peshkin, 2001; Wardman et al., 2010).

\section{End Notes}

1. We use these terms to illustrate the fractured nature of the middle classes, and to indicate that upper and elite middle class groups have greater material resources, some of whom might arguably be closer to the elite groups within British society (Ball et al., 2004, Bernstein, 1977, Maxwell and Aggleton, 2010, Méndez, 2008).

2. Institutional habitus is a term used in writing by Burke et al. (2013), Koh and Kenway (2012), Smyth and Banks (2012) among others.

3. Edler-Vass' (2007) paper directly tackles the concern that it is not possible to draw on both Bourdieu and Archer within the same conceptual framework. For some writers, see Crossley (2001) for instance, Bourdieu and Archer do not share the same position on whether and how reflexivity might drive practice (with Bourdieu arguably over-emphasizing the sedimented role of the habitus and Archer prioritising the potential of reflexivity), making their theoretical frameworks incompatible for thinking further about agency. We concur with Elder-Vass' (2007) overall conclusion, however, that 'most of our actions are co-determined by both our habitus and our reflexive deliberations ... [these] represent two complementary moments of one and the same process' (p. 335). 
4. The term 'agentic' was never used during the interviews - feeling good, pleased, proud, confident, in control were all phrases used to elicit the narration of experience and practices which may have been agentic.

5. Unlike our approach to selecting the young women to illustrate our argument in Maxwell \& Aggleton (2014), where we specifically selected girls from similar family backgrounds.

6. Avonscott School is a highly selective, girls' day school, and was also one of the schools in our sample. It is located in a different part of the geographical region our study focused on and is one of three girls' schools in the area recording very high end of Year 11 and 13 results nationally.

\section{References}

Ahearn, L. M. (2010). Agency and language. In J. Verschueren, J.-O. Östman \& J. Japsers (Eds.), Handbook of Pragmatics (pp. 28-48). Amsterdam: John Benjamins.

Allan, A. (2009). The Importance of being a 'Lady': Hyper-femininity and Heterosexuality in the Private, Single-Sex Primary School. Gender and Education, 21(2), 145-158.

Allan, A. (2010). Picturing success: young femininities and the (im)possibilities of academic achievement in selective, single-sex education. International Studies in Sociology of Education, 20(1), 39-54.

Allan, A., \& Charles, C. (2014). Cosmo girls: Configurations of class and femininity in elite educational settings. British Journal of Sociology of Education, 35(3): 333-352.

Allard, A. C. (2005). Capitalizing on Bourdieu: How useful are concepts of 'social capital' and 'social field' for researching 'marginalized' young women? Theory and Research in Education, 3(1), 63-79.

Archer, M. S. (2000). Being Human: The problem of agency. Cambridge: Cambridge University Press.

Archer, M. S. (2003). Structure, Agency and the Internal Conversation. Cambridge: Cambridge University Press.

Archer, M. S. (2012). The Reflexive Imperative in Late Modernity. Cambridge: Cambridge University Press.

Ball, S. J., Vincent, C., Kemp, S., \& Pietikainen, S. (2004). Middle class fractions, childcare and the 'relational' and 'normative' aspects of class practices. The Sociological Review, 54(4), 478-502.

Barnes, B. (2000). Understanding Agency - Social Theory and Responsible Action. London: Sage.

Beavis, C., \& Charles, C. (2007). Would the 'real' girl gamer please stand up? Gender, LAN cafés and the reformulation of the 'girl' gamer. Gender and Education, 19(6), 691-705.

Bell, S. A. (2012). Young people and sexual agency in rural Uganda. Culture, Health \& Sexuality, 14(3), 283-296.

Bernstein, B. (1977). Class, Codes and Control. Volume 3. London: Routledge. 
Block, D. (2012). Unpicking agency in sociolinguistic research with migrants. In M. Martin-Jones \& S. Gardner (Eds.), Multilingualism, Discourse and Ethnography (pp. 47-61). London: Routledge.

Bordonaro, L. I., \& Payne, R. (2012). Ambiguous agency: Critical perspectives on social interventions with children and youth in Africa. Children's Geographies, 10(4), 365-372.

Bryant, J., \& Schofield, T. (2007). Feminine Sexual Subjectivities: Bodies, Agency and Life History. Sexualities, 10(3), 321-340.

Bullen, E., \& Kenway, J. (2005). Bourdieu, subcultural capital and risky girlhood. Theory and Research in Education, 3(1), 47-61.

Burke, C. T., Emmerich, N., \& Ingram, N. (2013). Well-founded social fictions: A defence of the concepts of institutional and familial habitus. British Journal of Sociology of Education, 34(2), 165-182.

Butler, J. (2010). Performative Agency. Journal of Cultural Economy, 3(2), 147-161.

Clegg, S. (2006). The problem of agency in feminism: a critical realist approach. Gender and Education, 18(3), 309-324.

Clegg, S. (2013). The space of academia: Privilege, agency and the erasure of affect. In C. Maxwell \& P. Aggleton (Eds.), Privilege, Agency and Affect (pp. 71-87). Basingstoke: Palgrave Macmillan.

Collective, T. L. F. S. (2004). The problematization of agency in postmodern theory: as feminist educational researchers, where do we go from here? Gender and Education, 16(1), 2533.

Connell, R., Ashenden, D., Kessler, S., \& Dowsett, G. (1982). Making the Difference: Schools, Families and Social Division. Sydney: Allen \& Unwin.

Crossley, N. (2001). The phenomenological habitus and its construction. Theory and Society, 30(1), 80-120.

Crossley, N. (2006). Reflexive Embodiment in Contemporary Society. Maidenhead: Open University Press.

Currie, D. H., Kelly, D. M., \& Pomerantz, S. (2006). 'The geeks shall inherit the earth': Girls' Agency, Subjectivity and Empowerment. Journal of Youth Studies, 9(4), 419-436.

DeLissovoy, N. (2012). Education and violation: Conceptualizing power, domination, and agency in the hidden curriculum '. Race Ethnicity and Education, 15(4), 463-484.

Elder-Vass, D. (2007). Reconciling Archer and Bourdieu in an Emergentist Theory of Action. Sociological Theory, 25(4), 325-346.

Forbes, J., \& Lingard, B. (2013). Elite school capitals and girls' schooling: Understanding the (re)production of privilege through a habitus of 'assuredness'. In C. Maxwell \& P. Aggleton (Eds.), Privilege, Agency and Affect (pp. 50-68). Basingstoke: Palgrave Macmillan.

Gaztambide-Fernández, R. (2009). The Best of the Best: Becoming elite at an American boarding school. Cambridge, MA: Harvard University Press.

Gaztambide-Fernández, R., Cairns, K., \& Desai, C. (2013). The sense of entitlement. In C. Maxwell \& P. Aggleton (Eds.), Privilege, Agency and Affect (pp. 32-49). Basingstoke: Palgrave Macmillan.

Gonick, M., Renold, E., Ringrose, J., \& Weems, L. (2009). Rethinking Agency and Resistance. What Comes After Girl Power? Girlhood Studies, 2(2), 1-9.

Honey, J. R. D. S. (1977). Tom Brown's Universe: The development of the Victorian public school. London: Millington Books.

Howard, A. (2013). Negotiating privilege through social justice efforts. In C. Maxwell \& P. Aggleton (Eds.), Privilege, Agency and Affect (pp. 185-201). Basingstoke: Palgrave Macmillan. 
Irwin, S., \& Elley, S. (2013). Parents' hopes and expectations for their children's future occupations. The Sociological Review, 61(1), 111-130.

Keddie, A., \& Williams, N. (2012). Mobilising spaces of agency through genealogies of race and gender: Issues of indigeneity, marginality and schooling. Race Ethnicity and Education, 15(3), 291-309.

Khan, S. R. (2011). Privilege: The making of an adolescent elite at St. Paul's School. Princeton: Princeton University Press.

Koh, A., \& Kenway, J. (2012). Cultivating national leaders in an elite school: Deploying the transnational in the national interest. International Studies in Sociology of Education, 22(4), 333-351.

Lapping, C. (2013). Institutional accountability and intellectual authority: Unconscious fantasies and fragile identifications in contemporary academic practice. In C. Maxwell \& P. Aggleton (Eds.), Privilege, Agency and Affect. Basingstoke: Palgrave Macmillan.

Maxwell, C., \& Aggleton, P. (2010). Agency in action - young women and their sexual relationships in a private school. Gender and Education, 22(3), 327-343.

Maxwell, C., \& Aggleton, P. (2012a). Bodies and agentic practice in young women's sexual and intimate relationships. Sociology, 46(2), 306-321.

Maxwell, C., \& Aggleton, P. (2013a). Becoming accomplished: Concerted cultivation among privately educated young women. Pedagogy, Culture and Society, 21(1), 75-93.

Maxwell, C., \& Aggleton, P. (2013b). Middle class young women: Agentic sexual subjects? International Journal of Qualitative Studies in Education, 26(7), 848-865.

Maxwell, C., \& Aggleton, P. (Eds.). (2013c). Privilege, agency and affect. Basingstoke: Palgrave Macmillan.

Maxwell, C., \& Aggleton, P. (2014 online). The reproduction of privilege: Young women, the family and private education. International Studies in Sociology of Education.

Maxwell, J. D., \& Maxwell, M. P. (1995). The reproduction of class in Canada's elite independent schools. British Journal of Sociology of Education, 16(3), 309-326.

McCulloch, G. (1991). Philosophers and Kings: Education for Leadership in Modern England. Cambridge: Cambridge University Press.

McNay, L. (2000). Gender and agency: reconfiguring the subject in feminist and social theory. Cambridge: Polity Press.

McNay, L. (2003). Agency, anticipation and indeterminacy in feminist theory. Feminist Theory, $4(2), 139-148$.

Méndez, M. L. (2008). Middle class identities in a neoliberal age: tensions between contested authenticities. The Sociological Review, 56(2), 220-237.

Mizen, P., \& Ofosu-Kusi, Y. (2013). Agency as vulnerability: Accounting for children's movement to the streets of Accra. The Sociological Review, 61(2), 363-382.

Nielsen, H. B. (2013). Gender on class journeys. In C. Maxwell \& P. Aggleton (Eds.), Privilege, Agency and Affect (pp. 202-218). Basingstoke: Palgrave Macmillan.

Peshkin, A. (2001). Permissible Advantage? The Moral Consequences of Elite Schooling. Abingdon: Routledge.

Proweller, A. (1998). Constructing Female Identities. Meaning making in an upper middle class youth culture. Albany: State University of New York Press.

Reay, D. (2004). 'It's all becoming a habitus': beyond the habitual use of habitus in educational research. British Journal of Sociology of Education, 25(4), 431-444.

Reay, D., Crozier, G., \& Clayton, J. (2009). Strangers in Paradise'? Working-class students in elite universities. Sociology, 43(6), 1103-1121.

Renold, E., \& Ringrose, J. (2008). Regulation and rupture: Mapping tween and teenage girls' resistance to the heterosexual matrix. Feminist Theory, 9(3), 335-360. 
Ringrose, J., \& Renold, E. (2013). "F**k rape!": Exploring affective intensities in a feminist research assemblage. Qualitative Inquiry.

Smyth, E., \& Banks, J. (2012). 'There was never really any question of anything else': Young people's agency, institutional habitus and the transition to higher education. British Journal of Sociology of Education, 33(2), 263-281.

Vincent, C., \& Martin, J. (2002). Class, Culture and Agency: researching parental voice. Discourse: Studies in the Cultural Politics of Education, 23(1), 109-128.

Wardman, N., Gottschall, K., Drew, C., Hutchesson, R., \& Saltmarsh, S. (2013). Picturing natural girlhoods: Nature, space and femininity in girls' school promotions. Gender and Education, 25(3), 284-294.

Wardman, N., Hutchesson, R., Gottschall, K., Drew, C., \& Saltmarsh, S. (2010). Starry eyes and subservient selves: Portraits of 'well-rounded' girlhood in the prospectuses of all-girl elite private schools. Australian Journal of Education, 54(3), 249-261.

Westhaver, R. (2006). Flaunting and Empowerment: Thinking about Circuit Parties, the Body, and Power. Journal of Contemporary Ethnography, 35(6), 611-644.

Wetherell, M. (2013). Feeling Rules, Atmospheres and Affective Practice: Some reflections on the analysis of emotional episodes. In C. Maxwell \& P. Aggleton (Eds.), Privilege, Agency and Affect (pp. 221-239). Basingstoke: Palgrave Macmillan.

Youdell, D. (2004). Wounds and Reinscriptions: Schools, Sexualities and Performative Subjects. Discourse: Studies in the Cultural Politics of Education, 25(4), 477-493.

Youdell, D. (2006). Subjectivation and performative politics-Butler thinking Althusser and Foucault: intelligibility, agency and the raced-nationed-religioned subjects of education. British Journal of Sociology of Education, 27(4), 511-528. 